\title{
UVB radiation modifies protein and photosynthetic pigment content, volume and ultrastructure of marine diatoms
}

\author{
A. G. J. Buma ${ }^{1, *}$, H. J. Zemmelink ${ }^{1}$, K. Sjollema ${ }^{2}$, W. W. C. Gieskes ${ }^{1}$ \\ ${ }^{1}$ Department of Marine Biology, ${ }^{2}$ Department of Electron Microscopy, Biological Centre, University of Groningen, \\ PO Box 14, 9750 AA Haren, The Netherlands
}

\begin{abstract}
Three marine diatom species (Cyclotella sp., Nitzschia closterium and Thalassiosira nordenskioldii) were exposed to a range of daily doses of ultraviolet $\mathrm{B}$ radiation (UVBR: $280-320 \mathrm{~nm}$ ). The lowest UVBR treatments $\left(<2000 \mathrm{~J} \mathrm{~m}^{-2} \mathrm{~d}^{-1}\right.$. DNA weighted biologically effective dose, normalised at $300 \mathrm{~nm}$ : daily $B E D_{D N A} 300 \mathrm{~nm}$ ) resulted in decreased division rates, volume enlargement and elevated cellular protein and pigment content levels. The highest UVBR treatments (between 2000 and $3800 \mathrm{~J}$ $\mathrm{m}^{-2} \mathrm{~d}^{-1}$ daily $B E D_{D N A} 300 \mathrm{~nm}$ ) resulted in complete growth inhibition, accompanied by only minor changes in protein, pigments and cell volume. Recovery of cell division after UVBR exposure was decreasingly successful with increasing UVBR dose rates. Ultrastructural examination of exposed $C y-$ clotella cells indicated that high UVBR levels induced plasmolysis and disorientation of cell organelles. Lower levels $\left(<2000 \mathrm{~J} \mathrm{~m}^{-2} \mathrm{~d}^{-1}\right.$ daily $\left.B E D_{D N A} 300 \mathrm{~nm}\right)$ seemed to cause an increase in volume and the amount of chloroplasts. The results support the notion conceived earlier that UVBR causes DNA damage, an arrest in the S or G2 phase of the cell cycle, and consequently growth without cell division.
\end{abstract}

KEY WORDS: Ultraviolet radiation UV effects Marine diatoms - Cell cycle Cell size Growth rate Pigments Protein. Cyclotellasp. Nitzschiasp. Thalassiosirasp.

\section{INTRODUCTION}

Thinning of the stratospheric ozone layer will increase the amount of incident ultraviolet $B$ radiation (UVBR) as well as the UVBR/(UVAR + PAR) (ultraviolet $A$ and photosynthetically active radiation, respectively) ratio due to the distinct absorption of ultraviolet light by ozone (Cutchis 1974, Kerr \& McElroy 1993). Light of short wavelengths in the UV range of the spectrum penetrates to significant depths in clear seawater (Smith \& Baker 1979, Gieskes \& Kraay 1990), where it may affect marine communities. Many biological parameters are measured as indicators of the detrimental effect of UVBR on aquatic organisms (Cullen \& Neale 1994). Most commonly, short term ( $<1$ d) incubation experiments are carried out to quantify the effect of UV radiation on photosynthetic rate (Lorenzen 1979. Smith et al. 1980, Worrest et al. 1981, Cullen \& Lesser

\footnotetext{
·E-mail: a.g.j.buma@biol.rug.nl
}

1991, Helbling et al. 1992, Behrenfeld et al. 1993a, b Prézélin et al. 1994, Schofield et al. 1995). Studies of effects over longer time scales ( $>1$ d) have focussed on viability, growth rate reduction, nutrient metabolism or community composition (Worrest et al. 1978, Jokiel \& York 1984, Döhler 1985, Behrenfeld et al. 1992, Bothwell et al. 1993, Davidson et al. 1994). In some species an increase in cell size was found as a result of UVBR exposure (Karentz et al. 1991, Behrenfeld et al. 1992). Döhler (1985) found that low UVBR doses positively affected biomass production (dry matter and protein).

A major effect of UVBR on marine microrganisms is mediated by direct damage to DNA, as demonstrated by experimental studies (Karentz et al. 1991, Buma et al. 1995). DNA damage has been detected both in isolated DNA and in repair deficient bacteria incubated below the sea surface (Karentz \& Lutze 1990, Regan et al. 1992). Among the variety of lesions and breaks that can be induced in the DNA of living organisms, cyclobutane pyrimidine dimers, especially thymine 
dimers, prevail as a result of UVBR exposure (Tyrrell 1986 and references therein). Dimers hinder genome replication because the action of DNA polymerase is blocked (Setlow et al. 1963, Swenson \& Setlow 1966). However, DNA damage can be repaired, for example by photoreactivation (Sancar \& Sancar 1988). Buma et al. (1995) demonstrated that thymine dimers appear in nuclear DNA of Cyclotella sp. at low levels of UVBR $<2000 \mathrm{~J} \mathrm{~m}^{-2} \mathrm{~d}^{-1}$ DNA weighted (daily biologically effective dose: daily $B D_{D N A} 30 n$ nnt $)$. Although thymine dimers were readily removed in the period after UVBR exposure (Buma et al. 1996), DNA damage caused an arrest of the cell cycle in the $\mathrm{S}$ or $\mathrm{G} 2$ phase, judging from DNA synthesis patterns (Buma et al. 1996).

In this study, experiments were done to investigate the effects of prolonged UVBR exposure on growth rate, cell volume, protein content, pigment composition and ultrastructure of 3 common marine diatoms, Cyclotella sp., Thalassiosira nordenskioldii and Nitzschia closterium. The hypothesis is that growth rate reduction, caused by the interference of UVBR in the cell cycle, affects these cell characteristics.

\section{MATERIALS AND METHODS}

Experiments were done with 3 marine diatoms: Nitzschia closterium and Cyclotella sp., both obtained from the RUG (Rijksuniversiteit Groningen) culture collection (originally isolated from the North Sea), and Thalassiosira nordenskioldii derived from the German Bight (isolation: J. v. Beusekom). Cells were grown in $\mathrm{f} / 4$ medium based on artificial seawater with a salinity of $33 \%$ (Guillard 1976). The experiments were performed in a culture cabinet at a temperature of $15 \pm$ $1^{\circ} \mathrm{C}$ and a light-dark regime of $14 \mathrm{~h}$ light:10 h dark. Two types of culture chambers were used. In one type, cells were grown in $250 \mathrm{ml}$ polystyrene culture bottles to measure the influence of UVBR on division rate, protein content and pigment content. Samples for ultrastructural examination were also harvested from these culture bottles. In the other type, cells were grown in $300 \mathrm{ul}$ polystyrene wells to measure the influence of different UVBR levels on division rate, cell volume and the recovery of individual cells after a period of UVBR exposure. In both culture chambers cells were exposed to UVBR for 3 or $6 \mathrm{~h} \mathrm{~d}^{-1}$ in the middle of the light period and harvested when the cultures were still in the log phase of growth (after 5 or $6 \mathrm{~d}$ ). The intensity of PAR in the bottles and trays was $5 \pm 0.5 \mathrm{~W} \mathrm{~m}^{-2}$. The trays were closed with Texa colorless adhesive tape to prevent water loss due to vaporization.

The culture bottles and trays were placed on 2 plexiglass shelves, one transparent for UVBR and UVAR (not for UVCR; for transmission characteristics see
Steeneken et al. 1995) and one which blocks UVCR and UVBR, above a Philips TL 12 fluorescent lamp which served as the UVBR source. Spectral emission from the lamp ranged from 275 to $400 \mathrm{~nm}$ with an emission peak at $312 \mathrm{~nm}$. UV was filtered by both the polystyrene of the culture bottles and plexiglass of the trays (Fig. 1). The transmission of the materials was measured with a CARY spectrophotometer (Model 3e, UV-Visible, Varian). Spectral lamp emission was measured with an Optronics OL 752 spectroradiometer The Optronics OL 752 was calibrated using a $200 \mathrm{~W}$ Tungsten coiled-coil filament lamp. A gradient of UV doses was obtained by either using various exposure times ( 3 or $6 \mathrm{~h}$ ) or by altering the distance between the lamp and the cultures. UV spectra were weighted with the DNA action spectrum of Setlow (Setlow 1974), which was normalised at $300 \mathrm{~nm}$. Two $250 \mathrm{ml}$ polystyrene culture bottles were placed on the UV transparent perspex; 2 other bottles placed on nontransparent plexiglass served as reference bottles. To determine the response of cell division and cell volume to UV exposure, individual cells were placed in $300 \mu \mathrm{l}$ wells, up to a total of 20 to 30 individuals per species. One half of the trays was irradiated with UVBR, the other served as a blank. Cells in culture bottles were exposed to $0,750^{\circ}, 1500^{\circ}, 1510^{\circ}, 3130^{\circ}, 3820^{\circ} \mathrm{J} \mathrm{m}^{-2}$ $\mathrm{d}^{-1}$. Cells in the microwells were exposed to $0,450^{\circ}$, $820^{*}, 910^{\circ}, 1660^{\circ}, 2350^{\circ} \mathrm{J} \mathrm{m}^{-2} \mathrm{~d}^{-1}$ ( ${ }^{*}$ and $\cdots$ indicate 3 and $6 \mathrm{~h}$ UVBR exposure per day respectively), all daily biological effective doses (BED DNA $300 \mathrm{~nm}$ ) using Setlow's (1974) DNA action spectrum, normalised at $300 \mathrm{~nm}$. Daily BEDs up to $1700 \mathrm{~J} \mathrm{~m}^{-2} \mathrm{~d}^{-1}$ may be considered realistic for temperate regions, according to data presented by Behrenfeld et al. (1993b) and Crutzen (1992) for incident daily BEDs reaching mid-latitudes during summer months. Each day the cultures in the bottles were resuspended prior to sampling. Cells were

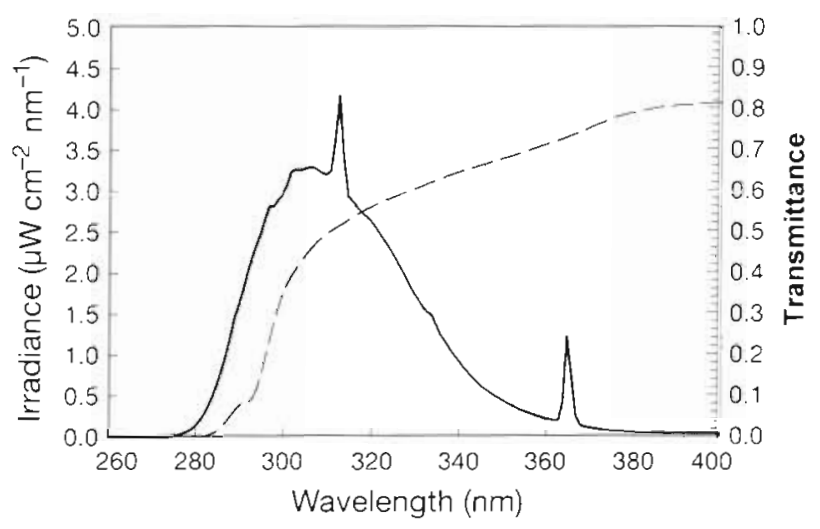

Fig. 1. Emission spectrum of Philips TL 12 (solid line) and transmission spectrum (dashed line) of the perspex+polystyrene combination, as used in the experiments (see "Materials and methods') 
counted with an inverted microscope. Division rate was calculated over the log phase by the number of divisions per $24 \mathrm{~h} \mid \mu=\left(\ln \mathrm{N}_{1}-\ln \mathrm{N}_{t 0}\right) / t$, where $\mathrm{N}=$ number of cells]. UVBR recovery was measured as the percentage of cells exhibiting cellular division after 1 wk of exposure to PAR only, following the UVBR treatments (see exposure experiments). Changes in cell volume were monitored in Cyclotella sp. only. Cell size increase could not be observed in cells of Nitzschia closterium and Thalassiosira nordenskioldii because the orientation of these cells in settling chambers hinders the observation of cells in girdle band view. Cell volumes were quantified by microscopic measurements of cellular dimensions at 200 to 400 magnification; Cyclotella sp. was considered as a cylinder.

For protein and pigment analyses $20 \mathrm{ml}$ of culture was harvested at the end of the experiment by centrifugation. Pellets were immediately stored at $-80^{\circ} \mathrm{C}$ until further use. Protein content per cell (pg) was measured in triplicate by Bradford's micro-assay standard procedure (Bradford 1976). Protein content of cultures exposed to $3130 \mathrm{~J} \mathrm{~m}^{-2} \mathrm{~d}^{-1}$ were measured with a Pye Unicam pu 8600 (UV/visible) spectrophotometer. All other protein contents were measured with a platereader Biorad model 3550 (UV/visible).

The following major diatom pigments were measured in duplicate: $\mathrm{chl} a_{1}$ chl $c_{1}$ and $c_{2}$, diadinoxanthin + diatoxanthin, and fucoxanthin. Pellets were extracted overnight in 1 to $2 \mathrm{ml}$ acetone (90\%). After filtration (Whatman GF/F glassfiber filter) 20 to $100 \mu l$ was injected into a HPLC system (Kratos) equipped with a RPC18 (5 $\mu \mathrm{m} 30 \mathrm{~cm}, \varnothing 3.9 \mathrm{~mm}$ ) column. The rate of solvent flow was $1 \mathrm{ml} \mathrm{min}{ }^{-1}$. Expansion of peaks was done using a reversed phase gradient elution method. The solvents used were (A) methanol: $\mathrm{H}_{2} \mathrm{O}: \mathrm{I} . \mathrm{P}$. (ion paring reagent) $=80: 18.75: 1.25$ [I.P. consists of $0.5 \mathrm{M}$ $\mathrm{C}_{16} \mathrm{H}_{37} \mathrm{NO}_{4} \mathrm{~S}$ and $\left.1 \mathrm{M}\left(\mathrm{NH}_{4}\right) 2 \mathrm{SO}_{4}\right]$ and (B) methanol: ethylacetate $=70: 30 ;$ gradient from $18 \% \mathrm{~B}$ to $100 \% \mathrm{~B}$ in $30 \mathrm{~min}$. Detection of pigments was done at $436 \mathrm{~nm}$ with an LKB 2141 detector. Integration of peak areas was done with the integration program Nelson (Perkin Elmer, Nelson Systems, Inc.). The pigment content per cell (pg) and the pigment ratio, relative to chl a (w/w $\times$ $100 \%$ ), were calculated.

For ultrastructural examination of UV effects, cells were harvested from the cultures exposed to 1510 and $3820 \mathrm{~J} \mathrm{~m}^{-2} \mathrm{~d}^{-1}$ by centrifugation and fixed immediately in $0.1 \%$ glutaraldehyde (final conc.) for $1 \mathrm{~h}$. After 2 rinses in cacodylate buffer at $\mathrm{pH} 7.2$ followed by 1 rinse in water the material was postfixed in $1.5 \% \mathrm{KMnO}_{4}$ for $15 \mathrm{~min}$ at $20^{\circ} \mathrm{C}$. After several rinsing steps with water the material was resuspended in uranylacetate and centrifuged for 10 to $15 \mathrm{~min}$ (16000 $\times g$ ). After $12 \mathrm{~h}$ incubation in $\mathrm{UoAcH}_{2} \mathrm{O}$ the pellets were dehydrated. Dehydration was achieved by using a stepwise increase in ethanol content up to $100 \%$ followed by a brief rinse in propyleneoxide for 5 min at $20^{\circ} \mathrm{C}$. Embedding was done in Epon. Cutting of the embedded material was done on an Ultrotome main unit type 4801A, followed by collection on grids and examination on a Philips EM 201 and a Philips CM 10 .

\section{RESULTS}

No significant differences in division rates were found between bottles and trays. As a result of the UVBR treatments, division rates declined in all species (Fig. 2A-C), Exposures of $6 \mathrm{~h} \mathrm{~d}^{-1}$ did not result in significantly higher division rates when the daily UVBR dose was virtually identical to the one received during the $3 \mathrm{~h}$ exposures. Recovery of growth after the UV treatment indicated that Nitzschia closterium was less

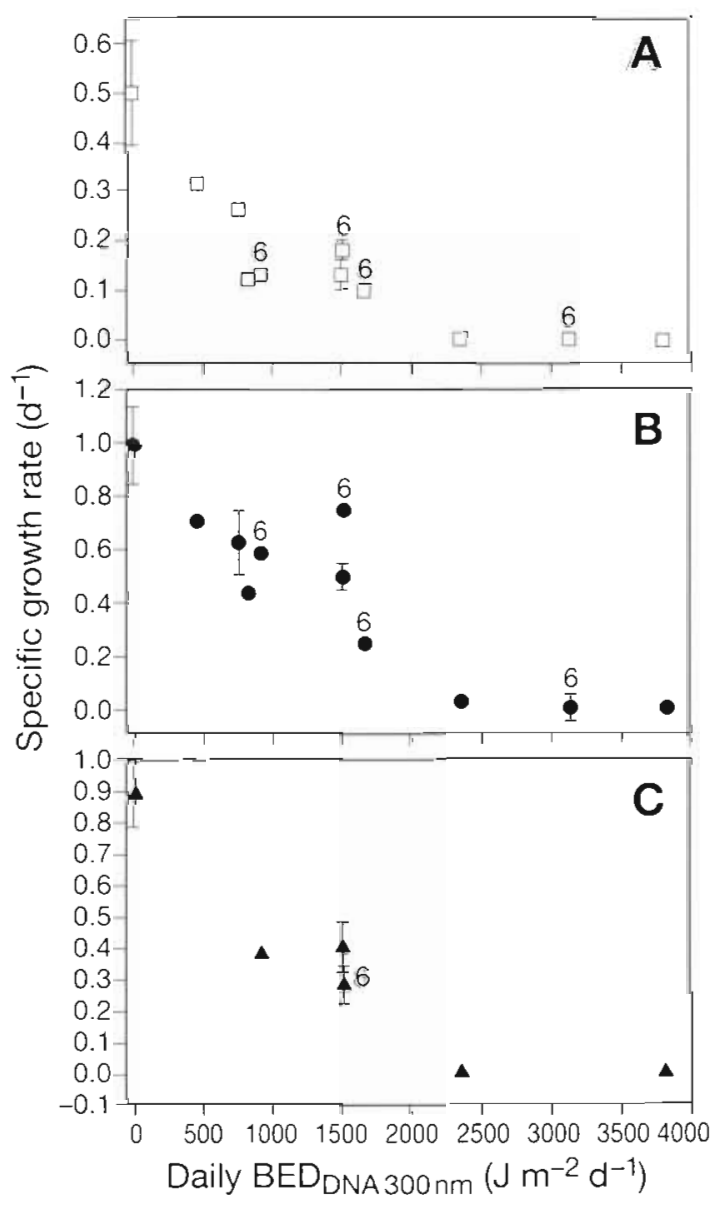

Fig. 2. Effect of UVBR on growth rates of 3 marine diatoms Error bars show standard deviations of the means. (A) Cyclotella sp.; (B) Nitzschia closterium; (C) Thalassiosira nordenskioldii. Data points marked with ' 6 ' represent the 6 h UVBR exposures; other data points refer to $3 \mathrm{~h}$ exposures 
successful in overcoming UVBR exposure than Cyclotella sp. Ten percent of Cyclotella sp. resumed cell division after an exposure to $2350 \mathrm{~J} \mathrm{~m}^{-2} \mathrm{~d}^{-1}$ while $N$. closterium and Thalassiosira nordenskioldii did not recover at all (Fig. 3) The lower rate of cell division as a result of exposures up to $1660 \mathrm{~J} \mathrm{~m}^{-2} \mathrm{~d}^{-1}$ was accompanied by a great increase in cell size in Cyclotella sp. (Fig 4). This increase in cell size did not, however, compensate for the decreased division rate so that total biovolume production in the cultures was much lower and decreased progressively with the level of radiation. At the highest level of radiation cell division stopped completely whereas cell size increase was less pronounced compared with the lower UVBR doses (Fig. 4).

All species showed a significant increase in cellular protein content at increasing UVBR exposures up to $1510 \mathrm{~J} \mathrm{~m}^{-2} \mathrm{~d}^{-1}(\mathrm{p}<0.05$; Fig. 5). Protein content of Cyclotella sp. increased up to 5 times the normal content. Exposure to 3130 and $3820 \mathrm{~J} \mathrm{~m}^{-2} \mathrm{~d}^{-1}$ caused a decrease in mean protein content per cell. These lower levels were not significantly different from those of the blank $(p<0.05)$. No significant difference was measured $(\mathrm{p}<0.05)$ between the cellular protein content of Nitzschia closterium after exposure to 1500 and $1510 \mathrm{~J} \mathrm{~m}^{-2} \mathrm{~d}^{-1}$, i.e. exposures of 3 and $6 \mathrm{~h}$ respectively. In contrast, Cyclotella sp. and Thalassiosira nordenskioldii showed a significant decrease in protein content per cell in spite of the minor increase in UV dose $(\mathrm{p}<0.05)$.

UVBR caused a cellular increase of all 4 pigments in Cyclotella sp. (Table 1), but exposure to the highest

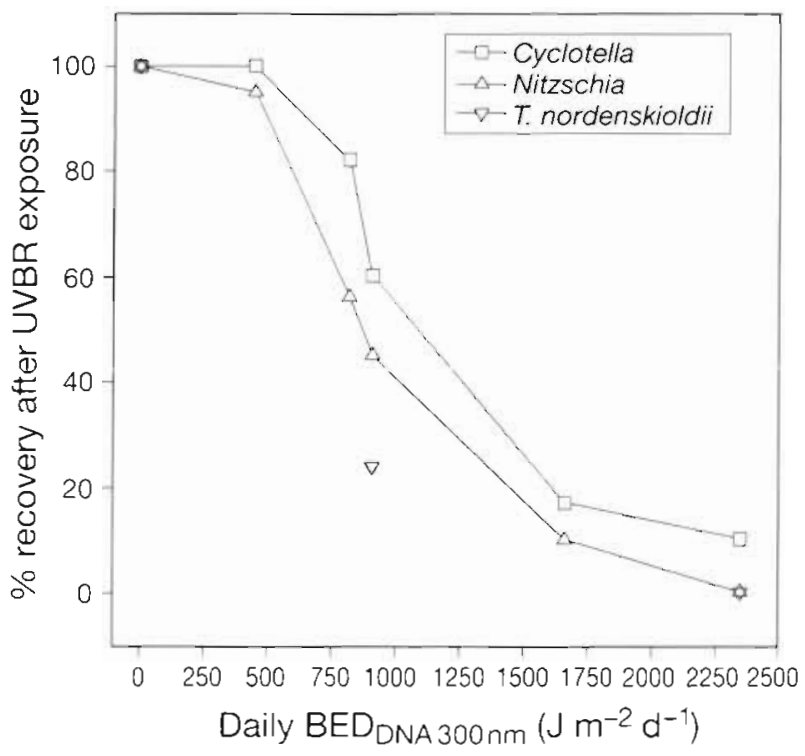

Fig. 3. Percentage of cells regaining growth 1 wk after the UVBR treatments. During the recovery period, cultures were exposed to PAR only (see 'Materials and methods')

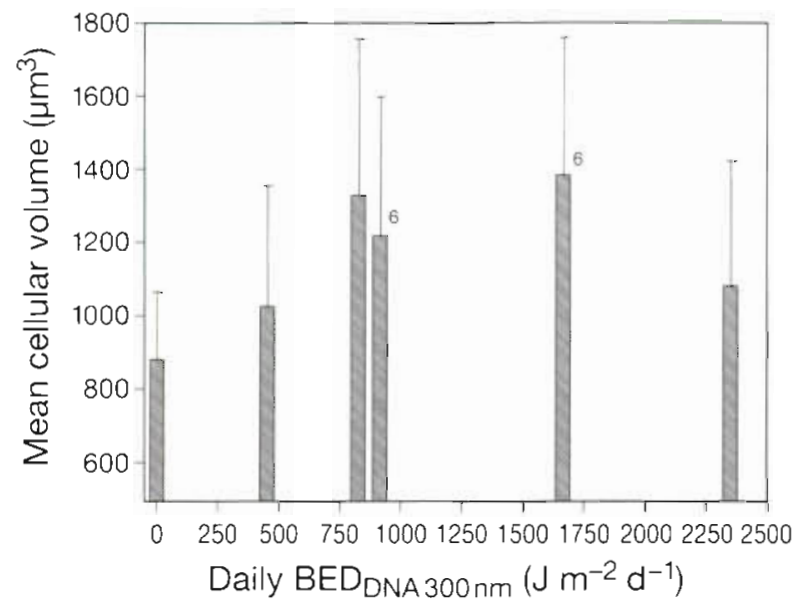

Fig. 4. Effect of UVBR on the mean cellular volume of Cyclotella sp. Error bars show standard deviations of the means. Data points marked with ' 6 ' represent the $6 \mathrm{~h}$ UVBR exposures; other data points refer to the 3 h exposures

level $\left(3820 \mathrm{~J} \mathrm{~m}^{-2} \mathrm{~d}^{-1}\right.$ ) resulted in a slight, albeit not significant, decrease $(p<0.05)$. After irradiation for $6 \mathrm{~h}$ $\mathrm{d}^{-1}$ a smaller increase in the light harvesting pigments was measured than after the $3 \mathrm{~h}$ irradiation treatments, except for the concentration of chl $c_{1}$ and $c_{2}$ which remained the same at increasing exposures (Table 1 ). Because of the similar effect on all pigments, increasing UVB exposure did not affect pigment ratios. Concentrations of light harvesting pigments of Nitzschia closterium and Thalassiosira nordenskioldii were not significantly affected by UV exposure (Table 1) Exposure to $3130 \mathrm{~J} \mathrm{~m}^{-2} \mathrm{~d}^{-1}$ caused a significant increase in diadinoxanthin + diatoxanthin cell ${ }^{-1}$ in $N$. closterium $(p<0.05)$ resulting in an increase of the ratio of diadinoxanthin + diatoxanthin to chl $a$ at an exposure to $3130 \mathrm{~J} \mathrm{~m}^{-2} \mathrm{~d}^{-1}$ UVBR $(\mathrm{p}<0.05)$. In $T$. nordenskioldii pigment ratios did not change at all.

On the ultrastructural level, similar effects were found for all 3 species when UVBR exposed cells were compared with unexposed log phase cells (Fig. 6, only shown for Cyclotella sp.). Unexposed interphase cells showed organised cell structures. Chloroplasts were found around the perimeter and the central nucleus was surrounded by the Golgi complex and a large vacuole (Fig. 6A, B). Also, a clear contrast between the nucleoplasm and the chromatin was found. After irradiation with $1510 \mathrm{~J} \mathrm{~m}^{-2} \mathrm{~d}^{-1}$ UVBR, cells increased in size (Fig. 6C). Sometimes, unusually long cells were found (Fig. 6D), by far exceeding the pre-mitotic cell length of unexposed cells (G2, of Fig 6A). Chloroplasts seemed to increase in number but to decrease in volume after UVBR exposure. The structure and the density of the thylakoids inside the chloroplasts did not seem to be affected when inspected at high magnification. Additionally, chloroplast distribution within the 


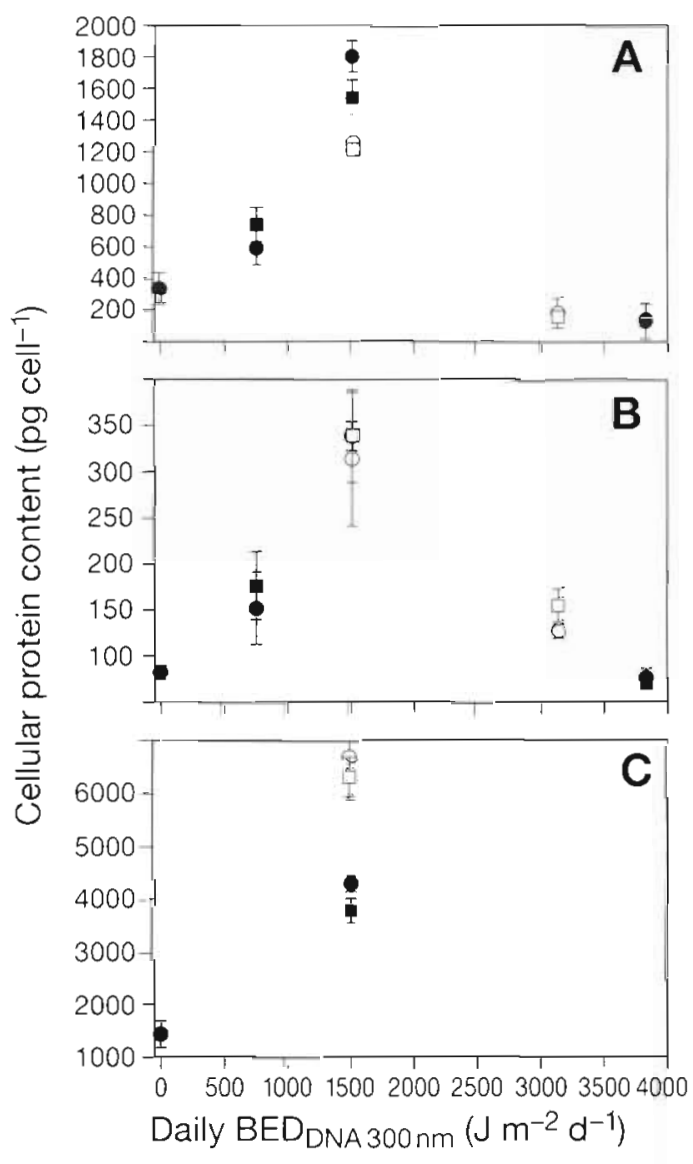

Fig. 5. Effect of UVBR on the mean protein content in 3 marine diatoms. $(0$, a) $6 \mathrm{~h}$ exposures; $(\bullet) 3 \mathrm{~h}$ exposures. Circles and squares represent duplicate experiments. (A) $\mathrm{Cy}$ clotella sp.i (B) Nitzschia closterium; (C) Thalassiosira nordenskioldii

cell lumen was less organised compared with unexposed cells (Fig. 6C). After irradiation with $3820 \mathrm{~J}$ $\mathrm{m}^{-2} \mathrm{~d}^{-1}$ many cells showed plasmolysis, judging from the formation of numerous small vacuoles filled with disintegrating cytoplasm (not shown). The nuclear envelope as well as the cell membranes and mitochondria seemed unaffected in all species. Finally, the contrast between the nucleolus, chromatine and nucleoplasm faded with increasing UVBR exposure.

\section{DISCUSSION}

The relative impact of ultraviolet light on various target processes (photosynthesis, nutrient uptake, DNA replication) under natural conditions is largely unknown. This is partly due to the fact that spectral conditions and exposure regimes in the natural underwater environment are very difficult to either measure or model. Whether a UVBR-induced effect will become manifest will be determined by the level of UVBR, the spectral composition of the light in the UVBR range, the sensitivity of the organism(s) involved, the exposure regime and the relative abundance of the longer wavelengths involved in repair, i.e. UVAR and PAR (Smith et al. 1992). The results presented here may therefore not be applicable to natural conditions. Even though the lower UVBR doses (daily BEDDNA300n $<2 \mathrm{~kJ} \mathrm{~m}^{-2} \mathrm{~d}^{-1}$ ) were within natural limits (Behrenfeld et al. 1993b), the UVR:PAR ratios were approximately 10 times higher than those found in nature, due to the low PAR irradiance levels used in the experiments. Certainly, wavelengths involved in repair were underrepresented in this study. The same may hold for wavelengths involved in UVR-induced photoinhibition. Daily incident BEDs for $53^{\circ} \mathrm{N}$, as calculated with the model of Björn \& Murphy (1985), are $1.71 \mathrm{~kJ} \mathrm{~m}^{-2}$ when using the action spectrum of Setlow (1974), $16.5 \mathrm{~kJ} \mathrm{~m}^{-2}$ when using the photoirhibition action spectrum of Cullen et al. (1992) and $9.27 \mathrm{~kJ} \mathrm{~m}^{-2}$ when using the DNA action spectrum of Quaite et al. (1992), all normalised at $300 \mathrm{~nm}$. A comparison with the spectral conditions in our experiments revealed virtually similar daily $B E D$ s for all 3 action spectra $\left(1.71 \mathrm{~kJ} \mathrm{~m}^{-2}\right.$ Setlow $_{300 \mathrm{~nm}} 1.865 \mathrm{~kJ} \mathrm{~m}^{-2}$ Cullen et $\mathrm{al}_{.300 \mathrm{~nm}} 1.47 \mathrm{~kJ} \mathrm{~m}^{-2}$ Quaite et $\left.\mathrm{al}_{.300 \mathrm{~mm}}\right)$. This indicates that photoinhibition was less involved in the UV stress observed here than can be expected under natural spectral conditions. Nevertheless, the results may be valuable in view of the possible mechanism(s) involved in growth rate reduction in marine microalgae as a result of prolonged UVBR exposure.

Table 1. Effect of different levels $\left(\mathrm{J} \mathrm{m}^{-2}\right)$ and lengths ( 3 or $6 \mathrm{~h}$ ) of UVBR exposure on pigment contents (pg cell ${ }^{-1}$ ) in 3 marine diatoms

\begin{tabular}{|c|c|c|c|c|}
\hline UVB & Chl a & Chl $c$ & $\begin{array}{l}\text { Fuco- } \\
\text { xanthin }\end{array}$ & $\begin{array}{l}\text { Diadino- } \\
\text { xanthin } \\
\text { + diato- } \\
\text { xanthin }\end{array}$ \\
\hline \multicolumn{5}{|c|}{ Cyclotella sp. } \\
\hline 0 & $10.0 \pm 3.4$ & $1.7 \pm 0.8$ & $3.7 \pm 1.1$ & $4.0 \pm 1.6$ \\
\hline $750(3 \mathrm{~h})$ & $30.7 \pm 5.7$ & $4.6 \pm 0.52$ & $8.9 \pm 1.5$ & $9.6 \pm 1.3$ \\
\hline $1500(3 \mathrm{~h})$ & $19.2 \pm 4.1$ & $1.3 \pm 0.3$ & $9.6 \pm 3.0$ & $8.0 \pm 2.7$ \\
\hline $1510(6 \mathrm{~h})$ & $45.1 \pm 3.4$ & $9.0 \pm 2.6$ & $11.7 \pm 1.1$ & $19.5 \pm 0.7$ \\
\hline $3130(6 h)$ & $18.7 \pm 1.1$ & 3.0 & $5.6 \pm 0.6$ & $6.2 \pm 0.9$ \\
\hline $3820(3 h)$ & $7.0 \pm 1.9$ & $2.3 \pm 0.4$ & $2.8 \pm 0.7$ & $0.1 \pm 0.0$ \\
\hline \multicolumn{5}{|c|}{ Nitzschia closterium } \\
\hline 0 & $8.6 \pm 2.4$ & $3.1 \pm 1.1$ & $3.9 \pm 1.8$ & $2.3 \pm 0.8$ \\
\hline $750(3 \mathrm{~h})$ & $8.8 \pm 1.7$ & $3.2 \pm 1.9$ & $3.7 \pm 1.2$ & $2.4 \pm 0.9$ \\
\hline $1500(3 \mathrm{~h})$ & $8.1 \pm 1.0$ & $2.1 \pm 0.3$ & $3.5 \pm 0.6$ & $2.8 \pm 0.4$ \\
\hline $1510(6 \mathrm{~h})$ & $6.1 \pm 0.2$ & $3.5 \pm 0.3$ & $3.3 \pm 0.3$ & $3.1 \pm 1.0$ \\
\hline $3130(6 \mathrm{~h})$ & $9.0 \pm 0.4$ & $2.9 \pm 1.8$ & $3.9 \pm 0.2$ & $5.6 \pm 0.2$ \\
\hline $3820(3 \mathrm{~h})$ & $10.3 \pm 0.6$ & $3.3 \pm 0.4$ & $7.9 \pm 0.3$ & $4.7 \pm 0.4$ \\
\hline \multicolumn{5}{|c|}{ Thalassiosira nordenskioldii } \\
\hline 0 & $137.7 \pm 35.2$ & $39.1 \pm 22.0$ & $54.5 \pm 31.0$ & $46.7 \pm 30.0$ \\
\hline $1500(3 \mathrm{~h})$ & $151.0 \pm 12.7$ & $45.1 \pm 3.6$ & $57.6 \pm 5.5$ & $51.2 \pm 2.3$ \\
\hline 1510 (6 h) & $194.0 \pm 4.6$ & $56.8 \pm 3.8$ & $85.9+2.9$ & $56.0 \pm 1.8$ \\
\hline
\end{tabular}



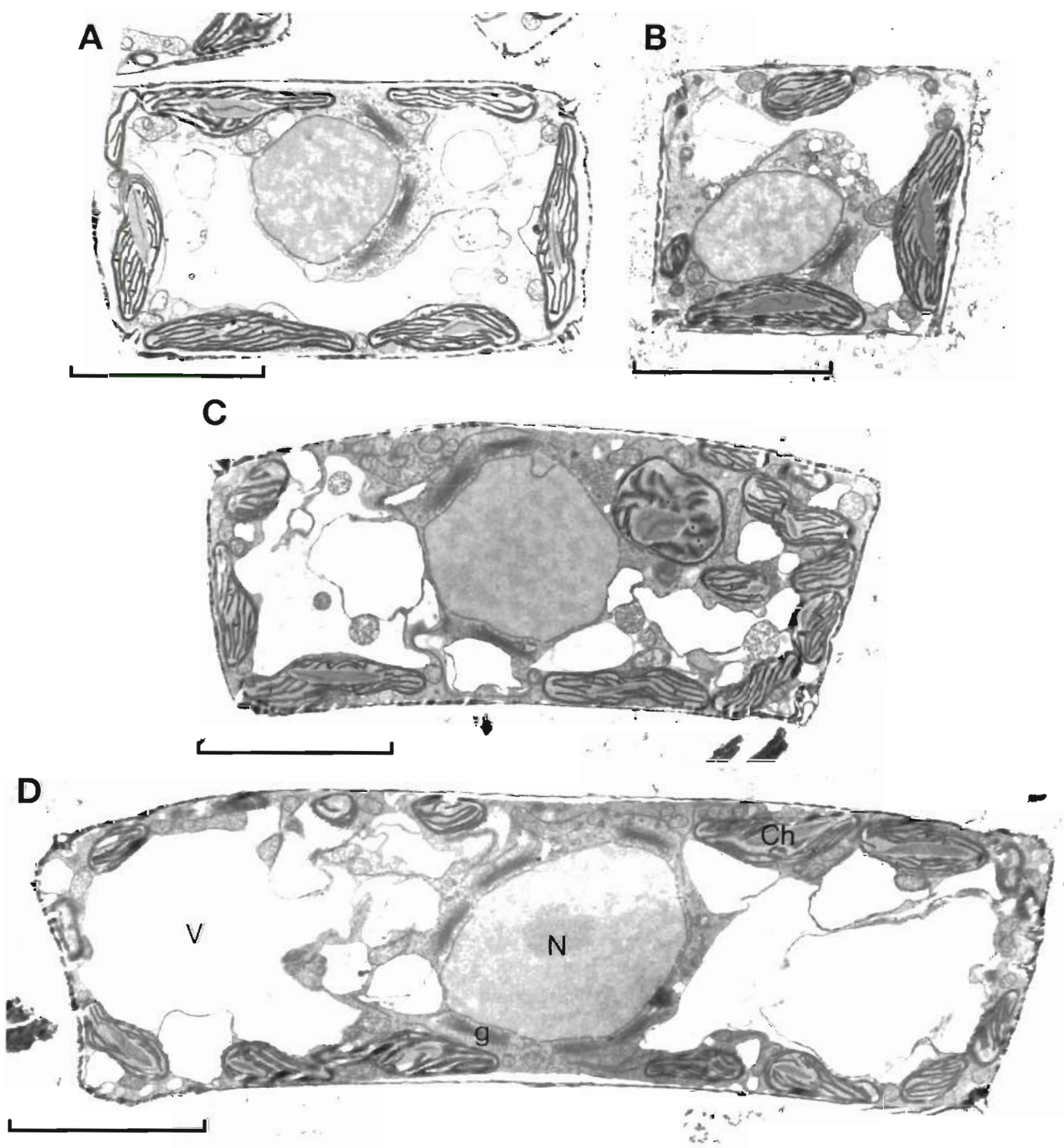

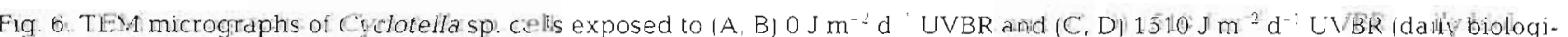
cally effective dose, DNA weighted, normalised at $300 \mathrm{~nm}$ ). (A.) Non-UVBR exposed cell during cell cycle progress, with increased cell volume and chloroplast number. (B) Non-UVBR exposed cell, recently divided. (C) UVBR exposed cell with increased cell volume, disorientation of cell organelles and increased number of chloroplasts. Note the enlarged nucleus. (D) UVBR exposed cell, with extreme increase in cell volume. V: vacuole; N: nucleus; g: Golgi apparatus; Ch: chloroplast. Scale bar $=5 \mu \mathrm{m}$

Decreased division rates at low UVBR exposures were typically accompanied by increases in cell size, protein and pigment content in Cyclotella sp., whereas at higher non-realistic doses these effects were not recorded. Karentz et a.l. (1991) and Behrenfeld et al. (1992) also found UVBR-induced increases in cell size, even under natural UVR conditions (Behrenfeld et al. 1992). All. species tested in our present study showed an increase in cellular protein content after exposure to low to moderate levels of UVBR. Elevated protein levels have also 
been found in plant leaves (Tevini 1981) and in another diatom (Döhler 1985) and may be associated with the biosynthesis of typical UV stress proteins, as demonstrated for several diatoms (Döhler et al. 1995). Finally, at low UVBR doses, an increase was found in Cyclotella sp. in cellular photosynthetic pigment contents, photoprotective carotenoids (diadinoxanthin + diatoxanthin), or both. This contrasts with numerous studies in which UVBR caused decreases in chlorophylls or carotenoids (Dohler 1985, Bidigare 1989). On the other hand, Döhler et al. (1991) showed an increase in the chl a content of diatoms exposed to low UVBR doses, whereas Adamse \& Britz (1992) found increases in chlorophylls in cucumber leaves upon exposure to UVBR.

Our data indicate that reciprocity holds for the species tested here: the $3 \mathrm{~h}$ and $6 \mathrm{~h}$ treatments gave comparable results for UVBR-induced growth rate reduction and changes in volume and protein. However, the scatter in our data set as well as the limited amount of observations do not seem satisfactory to justify such a conclusion. Moreover, reciprocity may not be accepted as a general rule, and may depend on the species or the parameter under consideration (Cullen \& Neale 1994, Helbling et al. 1994).

Our results support the hypothesis that DNA is one of the primary targets of UVBR (Karentz et al. 1991، Buma et al. 1995, 1996). DNA damage causes inhibition of DNA replication, which is a precondition for cell division. Cellular growth and synthesis of structural components require DNA transcription - not necessarily DNA replication - and occur during the whole interphase, but mainly during the G1 phase of the cell cycle. Since cellular growth as well as increases in cellular components were measured, low levels of UVBR do not seem to hinder transcription of DNA. Therefore, cell size as well as pigment and protein contents may have increased until the point where DNA damage prevented the cell from completing the DNA replication phase (S phase). DNA staining with Hoechst showed that nuclear division had not occurred in cells that showed cell volume enlargement (results not presented). The increase in pigment content per cell might be associated with an increase in the number of chloroplasts, the division of which is not mediated by nuclear DNA. This was supported by ultrastructural observations, where the amount of chloroplasts seemed to have increased at the low UVBR exposure. These results imply that UVBR has a stronger impact on nuclear DNA as compared to chloroplast DNA, possibly due to the protection of chloroplast DNA by surrounding pigments.

In contrast, higher UVBR exposures did not result in increased size and cellular components. In these cases growth was completely inhibited. It is likely that these high, non-realistic doses not only completely block metabolic processes (including protein and pigment biosynthesis), but also strongly reduce cell viability. This is supported by ultrastructural observations. which suggest that plasmolysis took place in most cells. Additionally, the recovery experiment showed survival in only a few percent of the Cyclotella sp. cells after high UVBR exposure. The recovery of cell division in visible light after exposure to low UVBR indicates that DNA repair mechanisms were operative, as found earlier in Cyclotella sp. (Buma et al. 1996). Behrenfeld et al. (1992) found that cell enlargement was reversible and that cells were able to regain their normal size after a UVBR exposure period. In our experiments, many Cyclotella sp. cells recovering from UVBR also regained their original size.

Within a population of Cyclotella sp. cells, a large variation in cellular DNA damage can be found, as monitored with flow cytometric detection of damage in individual cells (Buma et al. 1995). This means that within an exposed population a mixture of cells can be found which contain either undamaged DNA, slightly damaged/repairable DNA, or highly damaged/nonrepairable DNA. The data presented here suggest that repair becomes decreasingly successful with increasing UVBR doses and that the fraction of non-repairable and non-viable cells reaches $100 \%$ at the highest doses. Finally, growth rate reduction at the lower (realistic) UVBR doses may therefore be caused partly by a delay in mitosis until DNA damage is repaired and partly by the presence of a non-viable fraction

Acknowledgements. We are indebted to L. Villerius, A. Veen (RIVM, The Netherlands), R. Warnock, M. Eggens (RIKZ, The Netherlands) and J. Zagers for technical support and valuable suggestions. Suggestions of J. J. Cullen and several anonymous referees were greatly appreciated. This study was financed in part by the Dutch National Research Programme on Global Climate Change (NRP), project number 851054 .

\section{LITERATURE CITED}

Adamse P, Britz SJ (1992) Amelioration of UV-B damage under high irradiance. I: role of photosynthesis. Photochem Photobiol 56(5):645-650

Behrenfeld MJ, Chapman JW, Hardy JT, Lee H II (1993a) Is there a common response to ultraviolet-B radiation by marine phytoplankton? Mar Ecol Prog Ser 102:59-68

Behrenfeld M, Hardy J, Gucinski H, Hanneman A, Lee H II, Jones A (1993b) Effects of ultraviolet-B radiation on primary production along latitudinal transects in the south Pacific Ocean. Mar Environ Res 35:349-363

Behrenfeld MJ, Hardy JT, Lee H (1992) Chronic effects of ultraviolet-B radiation on growth and cell volume of Phaeodactylum tricornutum (Bacillariophyceae). J Phycol 28:757-760

Bidigare RR (1989) Potential effects of UV-B radiation on marine organisms of the Southern Ocean, distributions of phytoplankton and krill during austral spring. Photochem Photobiol 50:469-477

Bjön LO, Murphy TM (1985) Computer calculation of solar 
ultraviolet radiation at ground level. Physiol Veg 23(5): $555-561$

Bothwell ML, Sherbot D, Roberge AC, Daley RJ (1993) Influence of natural ultraviolet radiation on lotic periphytic diatom community growth, biomass accrual, and species composition: short term versus long term effects. J Phycol 28:24-35

Bradford MM (1976) A rapid and sensitive method for the quantification of microgram quantities of protein utilizing the principle of protein dye binding. Analyt Biochem 72: $248-254$

Buma AGJ, van Hannen EJ, Veldhuis MJW, Gieskes WWC (1996) UV-B induces DNA damage and DNA synthesis delay in the marine diatom Cyclotella sp. Sci Mar 60 (suppl 1): 101-105

Buma AGJ, van Hannen EJ, Veldhuis MJW, Roza L, Gieskes WWC (1995) Montoring UV-B induced DNA damage in individual diatom cells by immunofluorescent thymine dimer detection. J Phycol 31:314-321

Crutzen PJ (1992) Ultraviolet on the increase. Nature 356: $104-105$

Cullen JJ, Lesser MP (1991) Inhibition of photosynthesis by ultraviolet radiation as a function of dose and dosage rates: results for a marine diatom. Mar Biol 111:183-190

Cullen JJ, Neale PJ (1994) Ultraviolet radiation, ozone depletion, and marine photosynthesis. Photosynth Res 39: $303-320$

Cullen JJ, Neale PJ, Lesser MP (1992) Biological weighting function for the inhibition of phytoplankton photosynthesis by ultraviolet radiation. Science 258:646-650

Cutchis P (1974) Stratospheric ozone depletion and solar ultraviolet radiation on earth. Science 184(4132):13-19

Davidson AT, Bramich D, Marchant HJ, McMinn A (1994) Effects of UV-B radiation on growth and survival of Antarctic marine diatoms. Mar Biol 1 19:507-515

Dohler G (1985) Effect of UV-B radiation $(290-320 \mathrm{~nm})$ on the nitrogen metabolism of several marine diatoms. J Plant Physiol 118:391-400

Döhler G, Hagmeier E, Grigoleit E, Krause KD (1991) Impact of solar UV radiation on uptake of ${ }^{15} \mathrm{~N}$-ammonia and ${ }^{15} \mathrm{~N}$ nitrate by marine diatoms and natural phytoplankton. Biochem Physiol Pflanz 187:293-303

Döhler G, Hoffmann M. Stappel U (1995) Pattern of proteins after heat shock and UV-B radiation of some temperate marine diatoms and the Antarctic Odontella weissflogn. Bot Acta 108:93-98

Gieskes WWC, Kraay CW (1990) Transmission of ultraviolet Iight in the Weddell Sea: report of the first measurments made in the Antarctic. Biomass Newsletter 12:12-14

Guillard RRL (1976) Culturing of phytoplankton for feeding marine invertebrates. In: Smith WL, Chanley MH (eds) Culture of marine invertebrate animals. Plenum Publishing Co., New York, p 29-60

Helbling EW, Villafane V, Ferrärio M, Holm-Hansen O (1992) Impact of natural ultraviolet radiation on rates of photosynthesis and on specific marine phytoplankton species. Mar Ecol Prog Ser 80:89-100

Helbling EW, Villafane V, Holm-Hansen O (1994) Etfects of ultraviolet radiation on Antarctic marine photosynthesis with particular attention to the influence of mixing. In: Weiler CS, Penhale PA (eds) Ultraviolet radiation in Antarctica: measurements and biological effects. Antarctic Res Ser 62. Am Geophys Union, Washington. DC, p $207=229$

Jokiel PL, York RM Jr (1984) Importance of ultraviolet radiation in photoinhibition of microalgal growth. Limnol Oceanogr 29(1):192-199

Karentz, D, Cleaver EJ, Mitchell DL (1991) Cell survival char- acteristics and molecular responses of antarctic phytoplankton to ultraviolet-B radiation. J Phycol 27:326-341

Karentz D, Lutze LH (1990) Evaluation of biologically harmful ultraviolet radiation in Antarctica with a biological dosimeter designed for aquatic environments. Limnol Oceanogr 35:549-56]

Kerr JB, McElroy CT (1993) Evidence for large upward trends of ultraviolet-B radiation linked to ozone depletion. Sclence 262:1032-1034

Lorenzen CJ (1979) Ultraviolet radiation and phytoplankton photosynthesis. Limnol Oceanogr 24(6):1117-1120

Prézélin P. Boucher NP, Schofield O (1994) Evaluation of field studies of UVB radiation effects on Antarctic marine primary productivity. In: Biggs RH, Joyner MEB (eds) Stratospheric ozone depletion/UV-B radiation in the biosphere. NATO ASI Series Vol I, 18. Springer-Verlag, Berlin, p 181-194

Quaite FEB, Sutherland BM, Sutherland JC (1992) Action spectrum for DNA damage in alfalfa lowers predicted impact of ozone depletion. Nature 358:576-578

Regan JD, Carrier WL, Gucinski H, Olla BL, Yoshida H, Fujimura RK, Wicklund RI (1992) DNA as a solar dosimeter in the ocean. Photochem Photobıol 56:35-42

Sancar A, Sancar GB (1988) DNA repair enzymes. A Rev Biochem 57:29-67

Schofield O, Kroon BMA, Prézélin BB (1995) Impact of ultraviolet- $B$ radiation on photosystem II activity and its relationships to the inhibition of carbon fixation rates for Antarctic ice algae communities. J Phycol 31(5):703-715

Seflow RB (1974) The wavelengths in sunlight effective in producing skin cancer: a theoretical analysis. Proc Natl Acad Sci USA 7 1:3363-3366

Setlow RB, Swenson PA, Carrier WL (1963) Thymine dimers and inhibition of DNA synthesis by ultraviolet irradiation of cells. Science 142:1464-1465

Smith RC, Baker KS (1979) Penetration of UV-B and biologically effective dose-rates in natural waters. Photochem Photobiol 29:311-323

Smith RC, Baker KS, Holm-Hansen O, Olson R (1980) Photoinhibition of photosynthesis in natural waters. Photochem Photobiol 31:585-592

Smith RC, Prézélin BB, Baker KS, Bidıgare RR, Boucher NP, Coley T, Karentz D, MacIntyre S, Matlick HA, Menzies D, Ondrusek M, Wan Z, Waters KJ (1992) Ozone depletion: ultraviolet radiation and phytoplankton biology in Antarctic waters. Science 255:952-959

Steeneken SF, Buma AGJ, Gieskes WWC (1995) Changes in transmission characteristics of polymethylacrylate and cellulose ([Il) acetate during exposure to ultraviolet light. Photochem Photobiol 61(3):276-280

Swenson PA. Setlow RB (1966) Effects of ultraviolet radiation on macromolecular synthesis in Escherichia coli $\mathrm{J}$ Mol Biol 15:201-219

Tevini M. Iwanzik W. Thoma U (1981) Some effects of enhanced UV-B irradiation on the growth and composition of plants. Planta 153:388-394

Tyrrell RM (1986) Repair of genetic damage induced by UV-B (290-320 nm) radiation. In: Worrest RC, Caldwell MM (eds) Stratospheric ozone reduction, solar ultraviolet radiation and plant life. NATO ASI Series Vol G8 SpringerVerlag, Berlin, p 139-149

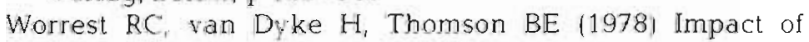
enhanced simulated solar ultraviolet radiation upon a marine community. Photochem Photobiol 27:471-478

Worrest RC, Wolniakowski KU, Scott JD, Brooker DL, Thomson $B E$, van Dyke $H$ (1981) Sensitivity of marine phytoplankton to UV-B radiation: impact upon a model ecosystem. Photochem Photobiol 33: 223-227 